\title{
Analisis Validitas Perangkat Pembelajaran Fisika Model Inkuiri Terbimbing untuk Meningkatkan Hasil Belajar Siswa SMA pada Materi Listrik Dinamis (The Analysis Validity of Physics Learning Device Guided Inquiry Model to Improve Student Learning Outcomes SMA on Dynamic Electrical Materials)
}

\author{
Aris Singgih Budiarso \\ Dosen Pendidikan IPA, Fakultas Keguruan dan Ilmu Pendidikan, Universitas Jember (UNEJ) \\ Jln. Kalimantan 37, Jember 68121 \\ E-mail: singgiharis.fkip@unej.ac.id
}

\begin{abstract}
Abstrak
Penelitian ini bertujuan untuk mendapatkan perangkat pembelajaran fisika model inkuiri terbimbing yang efektif untuk meningkatkan hasil belajar siswa SMA pada materi listrik dinamis. Penelitian ini mengacu pada model pengembangan Kemp. Hasil penelitian menunjukkan bahwa hasil pengembangan perangkat pembelajaran fisika layak untuk digunakan dalam pembelajaran fisika SMA dengan hasil sebagai berikut: rencana pelaksanaan pembelajaran mendapatkan skor 3,43 (valid), buku ajar siswa mendapatkan skor 3,30 (valid), lembar kerja siswa mendapatkan skor 3,30 (valid), tes hasil belajar kognitif siswa mendapatkan skor 3,35 (valid), lembar pengamatan psikomotor siswa mendapat skor 3,67 (sangat valid), dan lembar pengamatan afektif siswa mendapat skor 3,67 (sangat valid).
\end{abstract}

Kata Kunci : model inkuiri terbimbing, validitas perangkat pembajaran fisika.

Abstract

This study aims to obtain learning tools physics model guided inquiry effective to improve student learning outcomes SMA on dynamic electrical materials. This research refers to the Kemp development model. The result of the research shows that the result of the development of the physics learning device is feasible to be used in the learning with the following result: the learning implementation plan get the score 3,43 (valid), the student text get the score 3,30 (valid), the student worksheet get score 3, 30 (valid), concept mastering test get score 3,3 (very valid), and student character observation sheet got score 3,67 (very valid).

Keywords : guided inquiry model, validity of physics learning device.

\section{Pendahuluan}

Pendidikan merupakan suatu upaya untuk mencerdaskan kehidupan bangsa sebagaimana tertuang dalam UUNo. 20 Tahun 2003 tentang Sistem Pendidikan Nasional pada pasal 3 yang berbunyi: "pendidikan nasional berfungsi mengembangkan kemampuan dan membentuk karakter serta peradaban bangsa yang bermartabat dalam rangka mencerdaskan kehidupan bangsa. Pendidikan nasional bertujuan untuk berkembangnya potensi peserta didik agar menjadi manusia yang beriman dan bertakwa kepada Tuhan Yang Maha Esa, berakhlak mulia, sehat berilmu, cakap, kreatif, mandiri, dan menjadi warga Negara yang demokratis, serta bertanggung jawab".

Fisika sebagai bagian dari mata pelajaran yang diajarkan di Sekolah Menengah Atas berperan dalam mewujudkan tujuan pendidikan nasional tersebut mempunyai tujuan agar siswa siswa setelah mengikuti pembelajaran memiliki kemampuan sebagai berikut: (1) membentuk sikap positif terhadap fisika dengan menyadari keteraturan dan keindahan alam serta mengagungkan kebesaran Tuhan Yang Maha Esa; (2) memupuk sikap ilmiah yaitu jujur, obyektif, terbuka, ulet, kritis, dan dapat bekerjasama dengan orang lain; (3) mengembangkan pengalaman untuk dapat merumuskan masalah, mengajukan dan menguji hipotesis melalui percobaan, merancang dan merakit instrumen percobaan, mengumpulkan, mengolah, dan menafsirkan data, serta mengkomunikasikan hasil percobaan secara lisan dan tertulis; (4) mengembangkan kemampuan bernalar dalam berpikir analisis induktif dan deduktif dengan menggunakan konsep dan prinsip fisika untuk menjelaskan berbagai peristiwa alam dan menyelesaian masalah baik secara kualitatif maupun kuantitatif; dan (4) menguasai konsep dan prinsip fisika serta mempunyai keterampilan mengembangkan pengetahuan, dan sikap percaya diri sebagai bekal untuk melanjutkan pendidikan pada jenjang yang lebih tinggi, serta mengembangkan ilmu pengetahuan dan teknologi (BNSP, 2006).

Untuk mencapai tujuan pendidikan nasional di atas dan adanya suatu harapan kepada siswa setelah mengikuti pembalajaran fisika, maka fisika dalam pembelajarannya harus sesuai dengan hakekat IPA, yaitu: proses, produk, dan sikap ilmiah. Menurut Donosepoetro (dalam Trianto 2010) fisika yang merupakan bagian dari IPA pada hakikatnya dibangun atas dasar produk ilmiah, proses ilmiah dan juga sikap ilmiah. IPA sebagai proses ilmiah mempunyai makna yaitu semua kegiatan ilmiah dengan tujuan untuk menyempurnakan pengetahuan tentang alam ataupun untuk 
menemukan pengetahuan yang baru. IPA sebagai produk dapat diartikan sebagai hasil dari suatu proses yang dapat berupa pengetahuan dari proses ilmiah. IPA sebagai sikap ilmiah dapat diartikan sebagai langkah kerja, sikap, dan cara berpikir selama proses berlangsung yang pada akhirnya untuk mendapatkan suatu produk. Akan tetapi sesuai dengan hasil observasi dibeberapa sekolah negeri di wilayah surabaya ternyata : (1) metode pembelajaran fisika yang digunakan guru kurang inovatif, guru lebih sering menggunakan metode ceramah, tanya jawab, dan mengerjakan soal latihan atau dengan kata lain pembelajaran yang digunakan guru tidak berpusat pada siswa sehingga siswa tidak dapat menemukan pengetahuannya sendiri; (2) kurang adanya variasi dalam penggunaan model pembelajaran; (3) pelaksanaan pengembangan karakter siswa masih belum optimal. Indikasi belum optimalnya pengembangan karakter siswa tersebut dapat dilihat dari masih banyaknya siswa yang terlambat dalam mengumpulkan tugas, melihat jawaban teman, dan kurang sungguh-sungguh dalam mengerjakan tugas yang telah diberikan.

Oleh karena itu, perlu dilakukan inovasi pengembangan perangkat pembelajaran yang sesuai dengan karakteristik mata pelajaran fisika. Adapun model inkuiri terbimbing dipandang sesuai dengan hakekat pelajaran IPA fisika. Kesesuaian tersebut dikarenakan dalam pembelajarannya menghadapkan siswa pada masalah, mengumpulkan data, mengumpulkan data, mengolah, memformulasi suatu penjelasan, dan analisis proses penelitian (Joyce dan Weil, 2011). Selain itu, model inkuiri terbimbing juga merupakan suatu model yang mempersiapkan siswa pada situasi untuk melakukan eksperimen sendiri secara luas agar dapat melihat apa yang terjadi, ingin melakukan sesuatu, mengajukan pertanyaan-pertanyaan, serta mencari jawaban atas pertanyaan sendiri (Piaget dalam Mulyasa, 2006). Selanjutnya, Prince dan Felder (2007) juga menyatakan bahwa pada pembelajaran inkuiri terbimbing siswa disajikan tantangan berupa pertanyaan yang harus dijawab, pengamatan atau data yang ditetapkan untuk ditafsirkan, atau hipotesis yang akan diuji. Pada pembelajaran inkuiri terbimbing ini guru berperan membimbing siswa dalam menentukan permasalahan dan tahap-tahap pemecahan yang pada tahap awal guru banyak memberikan bimbingan, kemudian pada tahap berikutnya bimbingan dikurangi sehingga siswa mampu melakukan proses inkuiri secara mandiri. Model inkuiri terbimbing yang dalam pengembangannya mengkombinasikan nilai-nilai karakter (disiplin dengan harapan siswa memiliki sikap dan perilaku yang tertib serta patuh pada berbagai ketentuan dan peraturan, jujur dengan harapan siswa memiliki integritas yang akan menjadikannya sebagai pribadi yang mudah dipercaya dalam perkataan dan tindakan, serta tanggung jawab dengan harapan siswa memiliki sikap dan perilaku yang totalitas terhadap tugas serta kewajibannya sebagaimana yang seharusnya yang dia lakukan) dengan langkah-langkah yang ada di dalam model inkuiri terbimbing.

Model inkuiri terbimbing yang sudah terintegrasi nilainilai karakter yang ingin dikembangkan kepada siswa tersebut dalam pelaksanaan pembelajarannya dengan guru sebagai fasilitator dan pembimbing memberi kesempatan kepada siswa untuk merumuskan masalah melalui pertanyaan, membuat hipotesis dengan penuh tanggung jawab dan jujur, merancang dan melakukan percobaan, mengumpulkan data dengan tepat waktu, menganalisis data dengan jujur. Selain itu, pada tahap penutupnya memberi kesempatan kepada siswa untuk membuat kesimpulan dengan jujur dan tanggung jawab serta meminta siswa mengerjakan permasalahan sebagai penerapan dengan jujur, disiplin, dan tanggung jawab.

Berdasarkan uraian di atas, maka rumusan masalah yang pada penelitian ini yaitu "bagaimanakah kelayakan perangkat pembelajaran fisika model inkuiri terbimbing untuk meningkatkan hasil belajar siswa SMA pada materi listrik dinamis?".

\section{Metode Penelitian}

Penelitian ini merupakan penelitian pengembangan (developmental research) dengan rancangan pengembangan model Kemp et al (1994). Model pengembangan tersebut terdiri atas: (1) instructional problems, (2) learner characteristics, (3) task analysis, (4) instructional objectives, (5) content sequencing, (6) instructional strategies, (7) instructional delivery, (8) evaluation instrumens, dan (9) instructional resources. Pemilihan model ini dikarenakan tiap-tiap langkah pengembangannya berhubungan langsung dengan aktivitas revisi. Perangkat yang akan divalidasi meliputi: RPP, LKS (Lembar Kegiatan Siswa), BAS (Buku Ajar Siswa), tes hasil belajar kognitif siswa, lembar pengamatan psikomotor siswa, dan lembar pengamatan afektif siswa. Proses validasi tersebut dilakukan oleh 2 orang pakar sehingga akan menghasilkan data yang selanjutnya dianalisis secara deskriptif kualitatif. Pada penelitian ini skor rerata (P) dari hasil penilaian para pakar dan praktisi disesuaikan dengan kriteria penilaian perangkat sebagaimana dapat dilihat pada Tabel 1 .

Tabel 1 Kriteria Penilaian Validasi Perangkat Pembelajaran

\begin{tabular}{|l|l|l|}
\hline \multicolumn{1}{|c|}{ Interval Skor } & \multicolumn{1}{|c|}{$\begin{array}{c}\text { Kriteria } \\
\text { Penilaian }\end{array}$} & \multicolumn{1}{|c|}{ Keterangan } \\
\hline $3,6 \leq \mathrm{P}<4$ & Sangat valid & $\begin{array}{l}\text { Dapat digunakan tanpa } \\
\text { revisi }\end{array}$ \\
\hline $2,6 \leq \mathrm{P}<3,5$ & Valid & $\begin{array}{l}\text { Dapat digunakan } \\
\text { dengan sedikit revisi }\end{array}$ \\
\hline $1,6 \leq \mathrm{P}<2,5$ & Kurang valid & $\begin{array}{l}\text { Dapat digunakan } \\
\text { dengan banyak revisi }\end{array}$ \\
\hline $1 \leq \mathrm{P}<1,5$ & Tidak Valid & $\begin{array}{l}\text { Belum dapat digunakan } \\
\text { dan masih memerlukan } \\
\text { konsultasi }\end{array}$ \\
\hline
\end{tabular}

Pehitungan reliabilitas instrumen penilaian perangkat menggunakan rumus sebagai berikut:

$$
\mathrm{R}=[\mathrm{A} /(\mathrm{A}+\mathrm{D})] \times 100 \%
$$

Keterangan:

$\mathrm{R}=$ Reliabilitas Instrumen (percentage of agreement)

$\mathrm{A}=$ Frekuensi kecocokan antara kedua penilai (agree) 
$\mathrm{D}=$ Frekuensi ketidakcocokan antara kedua penilai (disagree)

Borich (1994) menyatakan setelah dihitung reliabilitasnya, maka instrumen tersebut dikatakan reliabel apabila memiliki reliabilitas $\geq 75 \%$.

\section{Hasil Penelitian}

Perangkat pembelajaran yang dikembangkan pada penelitian ini meliputi: Rencana Pelaksanaan Pembelajaran (RPP), Buku Ajar Siswa (BAS), Lembar Kegiatan Siswa (LKS), tes hasil belajar kognitif siswa, lembar pengamatan psikomotor siswa, dan lembar pengamatan afektif siswa. Proses pengembangan perangkat pembelajaran mengacu pada model pengembangan Kemp et al (1994). Selanjutnya, akan dijelaskan secara ringkas hasil pengembangan perangkat pembelajaran model inkuiri terbimbing.

1. Rencana Pelaksanaan Pembelajaran (RPP)

Rencana Pelaksanaan Pembelajaran (RPP) yang dikembangkan peneliti mengacu pada analisis karakteristik siswa dan format KTSP dengan mempertimbangkan keluasan materi yang disampaikan, maka RPP dibuat dalam 4 kali pertemuan dengan alokasi waktu 2 × 45 menit setiap pertemuaannya. RPP yang telah dikembangkan peneliti tersebut kemudian divalidasi oleh 2 orang ahli dengan hasil dapat dilihat pada Tabel 2

Tabel 2. Hasil Validasi Rencana Pelaksanaan Pembelajaran

\begin{tabular}{|l|l|c|c|c|l|}
\hline \multirow{2}{*}{ No. } & $\begin{array}{c}\text { Aspek } \\
\text { yang } \\
\text { Dinilai }\end{array}$ & \multicolumn{2}{|c|}{$\begin{array}{c}\text { Rata-rata Skor } \\
\text { Penilaian }\end{array}$} & $\begin{array}{c}\text { Rata- } \\
\text { rata }\end{array}$ & Kriteria \\
\cline { 3 - 6 } & $\begin{array}{c}\text { Validator } \\
1\end{array}$ & $\begin{array}{c}\text { Validator } \\
2\end{array}$ & & \\
\hline 1 & Format & 3.50 & 3.50 & 3.50 & Valid \\
\hline 2 & Isi & 3.08 & 3.15 & 3.12 & Valid \\
\hline 3 & Bahasa & 3.67 & 3.67 & 3.67 & Sangat \\
\hline
\end{tabular}

Kesimpulan : RPP yang dikembangkan layak untuk digunakan dengan sedikit melakukan perbaikan dan penyempurnaan lebih lanjut.

\section{Buku Ajar Siswa (BAS)}

Perangkat pembelajaran lain yang dikembangkan peneliti adalah Buku Ajar Siswa (BAS). Pengembangan BAS dilakukan didasarkan hasil telaah peneliti terhadap: (1) analisis karakteristik siswa (bertujuan untuk mengetahui tingkat perkembangan kognitif, latar belakang pengetahuan, dan latar belakang sosial budaya siswa); (2) analisis tugas (digunakan untuk mengidentifikasi materi yang dipilih); (3) permasalahan dalam pembelajaran dan analisis tujuan (untuk menentukan masalah yang mendasar yang dihadapi dan perlu diangkat dalam pengembangan perangkat pembelajaran model inkuiri terbimbing pada materi listrik dinamis ini dengan didasarkan pada kurikulum yang dikembangkan oleh direktorat pembinaan SMA, teori belajar yang relevan, dan tuntutan masa depan). Buku ajar siswa yang dikembangkan berdasarkan beberapa pertimbangan di atas, kemudian divalidasi oleh 2 orang ahli dengan hasil dapat dilihat pada Tabel 3 .

Tabel 3. Hasil Validasi Buku Ajar Siswa (BAS)

\begin{tabular}{|c|c|c|c|c|c|}
\hline No & $\begin{array}{c}\text { Aspek } \\
\text { yang } \\
\text { Dinilai }\end{array}$ & \multicolumn{2}{|l|}{ Rata-rata Skor Penilaian } & Rata- & Kriteria \\
\cline { 2 - 5 } & Validator 1 & $\begin{array}{c}\text { Validator } \\
\text { rata }\end{array}$ & \\
\hline $\begin{array}{l}\text { Kompo } \\
\text { nen } \\
\text { kelaya } \\
\text { kan isi }\end{array}$ & 3.12 & 3.32 & 3.22 & Valid \\
\hline 2 & $\begin{array}{l}\text { Kompo } \\
\text { nen } \\
\text { bahasa }\end{array}$ & 3.40 & 3.60 & 3.50 & Valid \\
\hline 3 & $\begin{array}{l}\text { Kompo } \\
\text { nen } \\
\text { penyajian }\end{array}$ & 3.13 & 3.25 & 3.19 & Valid \\
\hline
\end{tabular}

Kesimpulan : Buku siswa yang dikembangkan layak dijadikan buku panduan bagi siswa maupun guru dalam proses pembelajaran.

3. Lembar Kegiatan Siswa (LKS)

Perangkat pembelajaran selanjutnya yang dikembangkan peneliti adalah Lembar Kegiatan Siswa (LKS). LKS yang sudah dikembangkan tersebut kemudian divalidasi oleh 2 orang ahli dengan hasil dapat dilihat pada Tabel 4.

Tabel 4. Hasil Validasi Lembar Kerja Siswa

\begin{tabular}{|c|c|c|c|c|l|}
\hline No. & $\begin{array}{c}\text { Aspek } \\
\text { yang } \\
\text { Dinilai }\end{array}$ & \multicolumn{2}{|c|}{$\begin{array}{c}\text { Rata-rata Skor } \\
\text { Penilaian }\end{array}$} & \multirow{2}{*}{$\begin{array}{c}\text { Rata- } \\
\text { rata }\end{array}$} & Kriteria \\
\cline { 3 - 5 } & $\begin{array}{c}\text { Validator } \\
1\end{array}$ & $\begin{array}{c}\text { Validator } \\
2\end{array}$ & & \\
\hline 1 & Format & 3.34 & 3.34 & 3.34 & Valid \\
\hline 2 & Isi & 3.14 & 3.57 & 3.35 & Valid \\
\hline 3 & Bahasa & 3.14 & 3.28 & 3.21 & Valid \\
\hline \multicolumn{2}{|l|}{ Realibilitas instrumen } & & & $80 \%$ \\
\hline
\end{tabular}

Realibilitas instrumen

Kesimpulan : LKS yang dikembangkan layak digunakan oleh guru dalam pembelajaran

\section{Tes Hasil Belajar Kognitif Siswa}

Perangkat pembelajaran selanjutnya yang dikembangkan adalah tes hasil belajar kognitif siswa. Tes hasil belajar kognitif adalah alat evaluasi yang digunakan untuk mengukur kemampuan siswa. Soal yang telah dikembangkan tersebut kemudian divalidasi oleh 2 orang ahli dengan hasil dapat dilihat pada Tabel 5.

Tabel 5. Hasil Validasi Tes Hasil Belajar Kognitif Siswa

\begin{tabular}{|l|l|l|l|l|l|l|}
\hline \multirow{2}{*}{$\begin{array}{l}\text { Butir } \\
\text { Soal }\end{array}$} & \multicolumn{3}{|c|}{ Aspek yang Dinilai } & \multicolumn{2}{c|}{ Kesimpulan } \\
\cline { 2 - 6 } & \multicolumn{2}{|c|}{ Isi } & \multicolumn{2}{c|}{$\begin{array}{l}\text { Bahasa dan } \\
\text { Penulisan Soal }\end{array}$} & \multicolumn{2}{c|}{} \\
\cline { 2 - 6 } & $\begin{array}{l}\text { Valida } \\
\text { tor 1 }\end{array}$ & $\begin{array}{l}\text { Valida } \\
\text { tor 2 }\end{array}$ & $\begin{array}{l}\text { Valida } \\
\text { tor 1 }\end{array}$ & $\begin{array}{l}\text { Valida } \\
\text { tor 2 }\end{array}$ & $\begin{array}{l}\text { Valida } \\
\text { tor 1 }\end{array}$ & $\begin{array}{l}\text { Valida } \\
\text { tor 2 }\end{array}$ \\
\hline $\begin{array}{l}\text { Rata- } \\
\text { rata }\end{array}$ & 3,25 & 3,45 & 3,3 & 3,45 & 3,25 & 3,4 \\
\hline
\end{tabular}




\begin{tabular}{|c|c|c|c|c|c|c|}
\hline $\begin{array}{l}\text { Kriteri } \\
\mathrm{a}\end{array}$ & Valid & Valid & Valid & Valid & Valid & Valid \\
\hline \multicolumn{7}{|c|}{ Realibilitas instrumen } \\
\hline \multicolumn{7}{|c|}{$\begin{array}{l}\text { Kesimpulan : Tes hasil belajar kognitif yang telah } \\
\text { dikembangkan layak digunakan untuk menguku } \\
\text { kemampuan kognitif fisika siswa pada materi listrik } \\
\text { dinamis. }\end{array}$} \\
\hline
\end{tabular}

\section{Lembar Pengamatan Psikomotor Siswa}

Perangkat pembelajaran selanjutnya yang dikembangkan adalah instrumen pengamatan psikomotor siswa yang didasarkan dari kemampuan siswa dalam melakukan imitasi $\left(\mathrm{P}_{1}\right)$, manipulasi $\left(\mathrm{P}_{2}\right)$, prestisi $\left(\mathrm{P}_{3}\right)$, dan artikulasi $\left(\mathrm{P}_{4}\right)$. Kemampuan siswa dalam melakukan ke empat level psikomotor tersebut diamati dengan didasarkan rubrik penilaian yang telah dikembangkan. Instrumen penilaian psikomotor siswa yang telah dikembangkan tersebut kemudian divalidasi oleh 2 orang ahli dengan hasil dapat dilihat pada Tabel 6 .

Tabel 6. Hasil Validasi Lembar Pengamatan Psikomotor Siswa

\begin{tabular}{|l|l|c|c|c|c|}
\hline No. & $\begin{array}{c}\text { Aspek } \\
\text { yang } \\
\text { Dinilai }\end{array}$ & \multicolumn{2}{|c|}{$\begin{array}{c}\text { Rata-rata Skor } \\
\text { Penilaian }\end{array}$} & $\begin{array}{c}\text { Rata- } \\
\text { rata }\end{array}$ & Kriteria \\
\cline { 3 - 6 } & $\begin{array}{c}\text { Validator } \\
1\end{array}$ & $\begin{array}{c}\text { Validator } \\
2\end{array}$ & \\
\hline 1 & Isi & 4.00 & 4.00 & 4.00 & $\begin{array}{l}\text { Sangat } \\
\text { Valid }\end{array}$ \\
\hline 2 & Bahasa & 4.00 & 4.00 & $\begin{array}{c}4.00 \\
\text { Sangat } \\
\text { Valid }\end{array}$ \\
\hline 3 & $\begin{array}{l}\text { Kesimpu } \\
\text { lan }\end{array}$ & 4.00 & 3 & 3.50 & Valid \\
\hline \multicolumn{2}{l}{ Realibilitas instrumen } & & $78.88 \%$ \\
\hline
\end{tabular}

Kesimpulan : Lembar pengamatan psikomotor siswa yang telah dikembangkan layak digunakan sebagai instrumen untuk melakukan pengamatan.

\section{Lembar Pengamatan Afektif Siswa}

Perangkat pembelajaran selanjutnya yang dikembangkan adalah instrumen pengamatan afektif siswa (yang meliputi pengamatan terhadap aktivitas siswa dan perkembangan karakter siswa). Instrumen penilaian afektif siswa yang telah dikembangkan tersebut kemudian divalidasi oleh 2 orang ahli dengan hasil dapat dilihat pada Tabel 7.

Tabel 7. Hasil Validasi Lembar Pengamatan Afektif Siswa

\begin{tabular}{|l|l|c|c|c|l|}
\hline No. & $\begin{array}{c}\text { Aspek } \\
\text { yang } \\
\text { Dinilai }\end{array}$ & \multicolumn{2}{|c|}{$\begin{array}{c}\text { Rata-rata Skor } \\
\text { Penilaian }\end{array}$} & $\begin{array}{c}\text { Rata- } \\
\text { rata }\end{array}$ & Kriteria \\
\cline { 3 - 4 } & $\begin{array}{c}\text { Validator } \\
1\end{array}$ & $\begin{array}{c}\text { Validator } \\
2\end{array}$ & & \\
\hline 1 & Isi & 4.00 & 4.00 & 4.00 & $\begin{array}{l}\text { Sangat } \\
\text { valid }\end{array}$ \\
\hline 2 & Bahasa & 3.00 & 3.00 & 3.00 & $\begin{array}{l}\text { Sangat } \\
\text { valid }\end{array}$ \\
\hline 3 & Kesimpu & 4.00 & 4.00 & 4.00 & Sangat \\
\hline
\end{tabular}

\begin{tabular}{|l|l|l|l|}
\hline \multicolumn{1}{|l|}{ lan } & & & valid \\
\hline \multicolumn{2}{|l|}{ Realibilitas instrumen } & $100,00 \%$ \\
\hline
\end{tabular}

Kesimpulan : Lembar pengamatan afektif siswa yang telah dikembangkan layak digunakan sebagai instrumen untuk melakukan pengamatan

\section{Pembahasan}

\section{Rencana Pelaksanaan Pembelajaran (RPP)}

Berdasarkan Tabel 2 di atas dapat diketahui bahwa secara rata-rata RPP yang telah dikembangkan berkriteria valid. Hal ini dikarenakan sesuai dengan Permendiknas Nomor 41 Tahun 2007 tentang standar proses khususnya pada komponen-komponen pada RPP yang meliputi adanya identitas mata pelajaran, standar kompetensi, kompetensi dasar, indikator pencapaian kompetensi, tujuan pembelajaran, materi ajar, alokasi waktu, metode pembelajaran, kegiatan pembelajaran, penilaian hasil belajar, sumber belajar. Selain itu, RPP yang disusun ini valid karena pada aspek format, bahasa, dan isi telah sesuai atau memenuhi kriteria RPP yang baik (Majid, 2008). Akan tetapi pada aspek isi mendapatkan rata-rata paling kecil ketimbang kedua aspek tainnya. Hal tersebut dikarenakan masih perlu dilakukan perbaikan dalam hal menuliskan kompetensi dasar, indikator, tujuan pembelajaran, dan ketepatan antara indikator dengan kompetensi dasar. Selain itu juga perlu disesuaikan urutan materi dengan langkah-langkah model inkuiri terbimbing yang telah dikembangkan, serta urutan penyusunan RPP berdasarkan tingkat kesulitan materi dengan diawali konsep paling sederhana sampai dengan konsep yang paling rumit. Oleh karena itu, peneliti melakukan revisi sesuai dengan saran dari validator sehingga diharapkan setelah direvisi perangkat tersebut lebih dapat membantu dalam proses pembelajaran.

2. Buku Ajar Siswa (BAS)

Pengembangan BAS dilakukan didasarkan hasil telaah peneliti terhadap: (1) analisis karakteristik siswa (bertujuan untuk mengetahui tingkat perkembangan kognitif, latar belakang pengetahuan, dan latar belakang sosial budaya siswa); (2) analisis tugas (digunakan untuk mengidentifikasi materi yang dipilih); (3) permasalahan dalam pembelajaran dan analisis tujuan (untuk menentukan masalah yang mendasar yang dihadapi dan perlu diangkat dalam pengembangan perangkat pembelajaran model inkuiri terbimbing pada materi listrik dinamis ini dengan didasarkan pada kurikulum yang dikembangkan oleh direktorat pembinaan SMA, teori belajar yang relevan, dan tuntutan masa depan). Sesuai dengan Tabel 2 di atas diketahui bahwa secara rata-rata ketiga aspek mempunyai rerata kriteria valid, yang artinya buku ajar siswa yang dikembangkan layak digunakan dalam proses pembelajaran. Rerata yang valid tersebut dikarenakan buku ajar yang dikembangkan sesuai dengan Permendiknas No 2 Tahun 2008 pasal 1 nomor 3 yang menyebutkan bahwa buku teks pelajaran pendidikan dasar, menengah, dan perguruan tinggi yang selanjut-nya disebut buku teks adalah buku acuan wajib untuk digunakan di satuan pendidikan dasar dan menengah atau perguruan tinggi yang memuat materi pembelajaran dalam rangka 
peningkatan keimanan, ketakwaan, akhlak mulia, dan kepribadian, penguasaan ilmu pengetahuan dan teknologi, peningkatan kepekaan dan kemampuan estetis, peningkatan kemampuan kinestetis dan kesehatan yang disusun berdasarkan standar nasional pendidikan. Akan tetapi ada beberapa revisi yang perlu dilakukan yaitu: penyusunan urutan materi berdasarkan tingkat kesulitan materi dengan diawali konsep paling sederhana sampai dengan konsep yang paling rumit dan tidak meninggalkan keterkaitan antar konsep pada materi tersebut, serta gunakan contoh-contoh yang sesuai dengan fakta dalam kehidupan sehari-hari.

3. Lembar Kegiatan Siswa (LKS)

LKS tersebut dalam proses pengembangannya berdasarkan beberapa analisis yang meliputi: (1) analisis tujuan (mengacu pada beberapa teori tentang model inkuiri terbimbing sebagai pertimbangan dalam menyusun tahaptahap LKS inkuiri terbimbing sehingga LKS tersebut mencerminkan karakter inkuiri terbimbing yang diawali dengan tahap merumuskan masalah melalui pertanyaan, membuat hipotesis, merancang dan melakukan percobaan, mengumpulkan dan menganalisis data, serta membuat kesimpulan. Selain itu, dalam penyusunannya LKS mengacu pada beberapa teori belajar yaitu teori Piaget tentang skema, teori Vygotsky tentang zona perkembangan proksimal dan scaffolding, serta teori Bruner tentang pembelajaran penemuan); (2) analisis karakteristik siswa (bertujuan untuk mengetahui tingkat perkembangan kognitif yang menurut teori Piaget (dalam Sagala, 2011) siswa pada kelompok usia 11 tahun ke atas berada dalam tahap operasi formal atau mereka telah mampu untuk berfikir abstrak. Jadi, pada tahap ini para siswa sudah mampu menyelesaikan masalah dengan cara yang lebih baik dan kompleks daripada anak yang masih berada dalam tahap operasional konkrit); (3) analisis tugas (digunakan untuk mengidentifikasi materi yang dipilih).

Tabel 4 di atas menunjukkan bahwa ketiga aspek yaitu: aspek format, aspek bahasa, dan aspek isi secara rata-rata berkriteria valid. Hal ini berarti LKS yang telah dikembangkan layak dan dapat digunakan sebagai perangkat pembelajaran dengan beberapa revisi yaitu: untuk semua LKS yang dikembangkan disesuaikan dengan karakter LKS inkuiri terbimbing dan diusahakan sampai mendapatkan formulasi fisika yang disesuaikan dengan konsep yang sedang dibahas di LKS dan untuk LKS I yaitu arus listrik dan hukum Ohm, harap diperhatikan grafik hubungan antara kuat arus listrik dengan beda potensial listrik, serta untuk LKS 4 yaitu energi dan daya listrik, apabila tidak menggunakan kWh-meter, maka lakukan penyetaraan energi listrik dengan memanaskan air berdasarkan konsep kalor.

4. Tes hasil belajar kognitif

Pengembangan tes hasil belajar kognitif tersebut didasarkan pada rumusan tujuan pembelajaran yang dihubungkan dengan tingkat berfikir domain kognitif Blomm, yaitu kemampuan untuk menyatakan kembali konsep atau prinsip yang telah dipelajari sebagai kemampuan intelektual yang meliputi kemampuan siswa untuk mengingat $\left(\mathrm{C}_{1}\right)$, memahami $\left(\mathrm{C}_{2}\right)$, menerapkan $\left(\mathrm{C}_{3}\right)$, menganalisis $\left(\mathrm{C}_{4}\right)$, mensintesis $\left(\mathrm{C}_{5}\right)$, dan mengevalusi $\left(\mathrm{C}_{6}\right)$ konsep listrik dinamis. Adapun soal yang dikembangkan adalah sebanyak 20 butir soal dengan rincian 9 soal untuk konsep arus listrik dan hukum Ohm, 4 soal untuk konsep rangkaian hambatan listrik, 5 soal untuk konsep hukum Kirchhoff, dan 2 soal untuk energi dan daya listrik.

Rata-rata yang valid pada semua aspek yang divalidasi sebagaimana ditunjukkan Tabel 4 di atas dikarenakan dalam pengembangan tes penguasaan konsepnya menggunakan panduan penulisan butir soal dengan langkah-langkah sebagai berikut: (1) menentukan tujuan penilaian; (2) memperhatikan standarkompetensi (SK) dan kompetensi dasar(KD); (3) menentukan jenis alat ukurnya; (4) menyusun kisi-kisi tes dan menulis butir soal beserta pedoman penskorannya (Direktorat Pembinaan SMA, 2010).

5. Lembar Pengamatan Psikomotor Siswa

Kriteria valid dan sangat valid sesuai Tabel 6 di atas dikarenakan selama proses pengembangan instrumen ini menggunakan pedoman khusus pengembangan instrumen dan penilaian ranah psikomotor direktorat pendidikan menengah umum tentang prosedur pembelajaran psikomotor meliputi :(1) menentukan tujuan dalam bentuk perbuatan; (2) menganalisis keterampilan secara rinci dan berurutan; (3) mendemonstrasikan keterampilan disertai dengan penjelasan

singkat dengan memberikan perhatian pada butir-butir kunci termasuk kompetensi kunci yang diperlukan untuk menyelesaikan pekerjaan dan bagian-bagian yang sukar; (4) memberi kesempatan kepada peserta didik untuk mencoba melakukan praktik dengan pengawasan dan bimbingan; (5) memberikan penilaian terhadap usaha peserta didik.

\section{Lembar Pengamatan Afektif Siswa}

Rata-rata kriteria valid dan sangat valid tersebut pada Tabel 7 di atas tercapai karena instrumen telah memenuhi syarat penyusunan instrumen yang baik, yaitu: (1) butir pertanyaan atau pernyataan sesuai dengan indikator; (2) bahasa yang digunakan komunikatif dan menggunakan tata bahasa yang benar; (3) butir peranyaaan/pernyataan tidak bias; (4) format instrumen menarik untuk dibaca; (5) pedoman menjawab atau mengisi instrumen jelas; dan (6) jumlah butir dan/atau panjang kalimat pertanyaan atau pernyataan sudah tepat sehingga tidak menjemukan untuk dibaca atau dijawab (BSNP, 2007).

\section{Kesimpulan dan Saran}

Hasil pengembangan perangkat pembelajaran fisika layak untuk digunakan dalam pembelajaran fisika SMA. Adapun saran untuk pengembangan perangkat pembelajaran fisika berikutnya lebih memperhatikan karakteristik peserta didik dan kurikulum yang berlaku.

\section{Ucapan Terima Kasih}

Penulis mengucapkan terima kasih kepada validator dan rekan dosen program studi pendidikan IPA FKIP Unej yang telah membantu dalam menyelesaikan penelitian ini.

\section{Daftar Pustaka}

[1] Badan Standart Nasional pendidikan (BNSP), Depdikbud. 2006 Standar Isi untuk Satuan Pendidikan Dasar dan Menengah. Jakarta : Depdikbud.

[2] Trianto. 2010. Mendesain Model Pembelajaran Inovatif- Progesif Jakarta: Kencana. 
[3] Joyce, B dan Weil, M. 2011. Models of Teaching: Model-model Pengajaran. Yogyakarta: Pustaka Pelajar.

[4] Mulyasa. 2006. Kurikulum Berbasis Kompetensi. Bandung: PT Remaja Rosda Karya.

[5] Prince dan Felder. 2007. The Many Faces of Inductive Teaching and Learning. National Science Teachers Association.

[6] Kemp, J.E., Gary, R.M. and Steven, M.R. 1994. Designing Effective Instruction. New York : Macmillan College Publishing Company.

[7] Borich, G. (1994). Observation Skill for Effective Teaching. New York: Mac Millan Publishing Company.

[8] Majid, Abdul. Perencanaan Pembelajaran : Mengembangkan Standar Kompetensi Guru. Bandung : PT Remaja Rosdakarya.

[9] Sagala, S. 2004. Konsep dan Makna Pembelajaran. Bandung: Alfabeta.

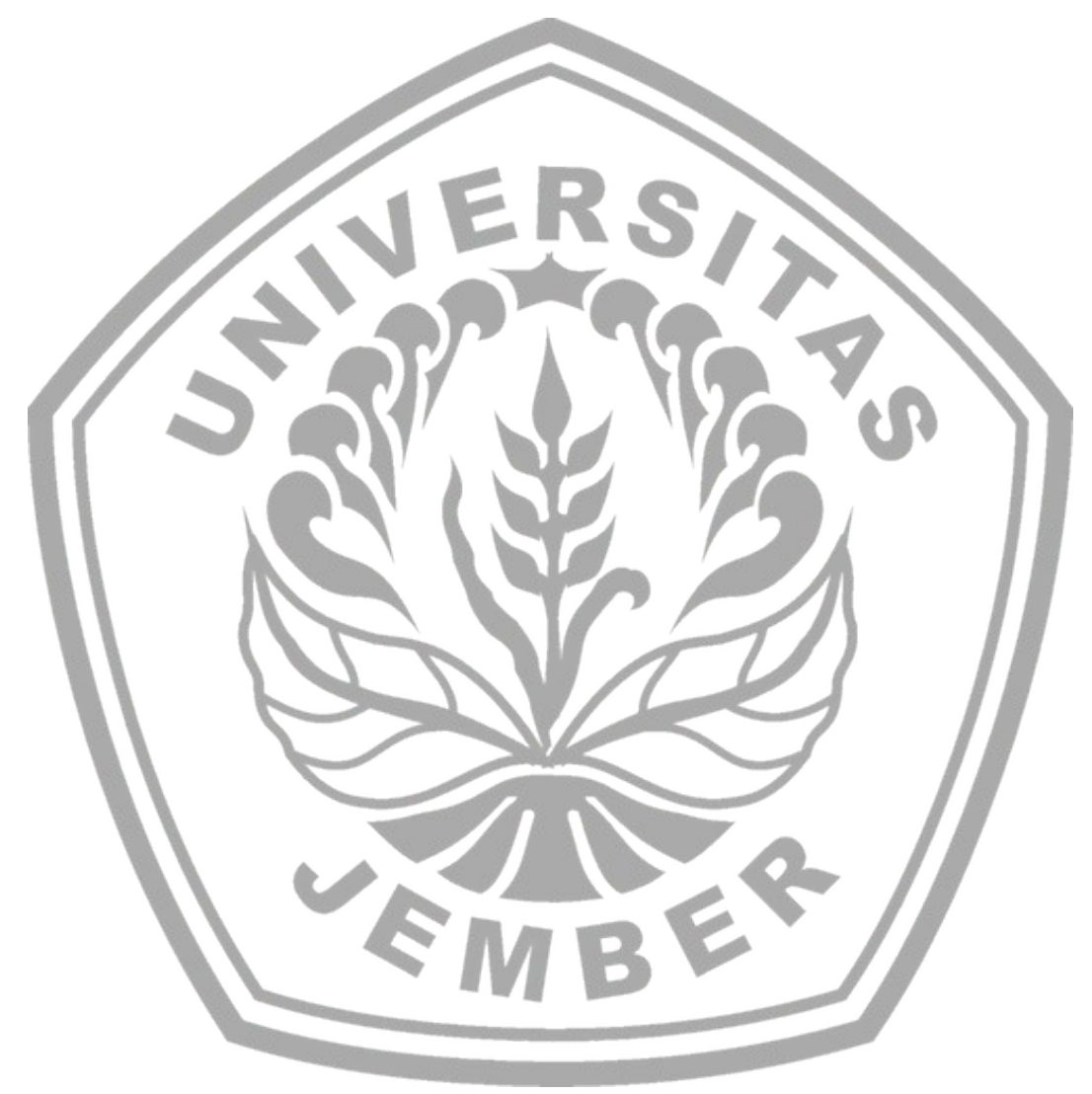

